\title{
Solar cell temperature on Mars
}

\author{
Alfonso Delgado-Bonal ${ }^{\mathrm{a}, \mathrm{b}, \mathrm{c}, *}$, F. Javier Martín-Torres ${ }^{\mathrm{c}, \mathrm{d}}$ \\ ${ }^{a}$ Centro de Astrobiología (INTA-CSIC), Ctra. Ajalvir km.4, Torrejón de Ardoz, 28850 Madrid, Spain \\ ${ }^{\mathrm{b}}$ Instituto Universitario de Física Fundamental y Matemáticas, Universidad de Salamanca, Casas del Parque, 37007, Spain \\ ${ }^{\mathrm{c}}$ Instituto Andaluz de Ciencias de la Tierra (CSIC-UGR), Avda. de Las Palmeras n 4, Armilla, 18100 Granada, Spain \\ ${ }^{\mathrm{d}}$ Division of Space Technology, Department of Computer Science, Electrical and Space Engineering, Lulea University of Technology, Kiruna, Sweden
}

Received 11 October 2014; received in revised form 23 February 2015; accepted 21 April 2015

Communicated by: Associate Editor Brian Norton

\begin{abstract}
The operating temperature of a solar cell determines its efficiency and performance. This temperature depends on the materials used to build the cell but also on the environmental variables surrounding it (i.e., radiation, ambient temperature, wind speed and humidity). Several equations have been proposed to calculate this temperature, depending on these variables. Also, for Earth conditions, simplified equations have been developed, but are not valid for other planets, as Mars, where the environmental conditions are extremely different. In this paper, we develop a simplified equation to calculate the temperature of a solar cell under Mars environmental conditions and discuss the effect that altitude and wind on Mars might have on the solar cell temperature. The correct determination of the operating temperature of the cell will help to optimize the design of the next solar cell powered rovers for the exploration of Mars.
\end{abstract}

(C) 2015 Elsevier Ltd. All rights reserved.

Keywords: Mars environment; Solar cell temperature; Rover; Lander; Space exploration missions

\section{Introduction}

The operating temperature of a solar cell is a key factor for its efficiency, and has implications on its performance and ability to produce electricity. Although the materials and design of fabrication has implications on the temperature of the cell, the environment surrounding it is a key factor for the determination of the temperature.

On Earth there are several physical processes affecting the temperature of the cell. On one side, the irradiance reaching the panel is converted to electrical energy, but also heats the cell. On the other hand, the wind refrigerates the

\footnotetext{
* Corresponding author at: Instituto Universitario de Física Fundamental y Matemáticas, Universidad de Salamanca, Casas del Parque, 37007, Spain. Tel.: +34 958190019 .

E-mail address: adelgado@cab.inta-csic.es (A. Delgado-Bonal).
}

cell by convection, and the difference of temperature with the environment allows the cell to loss heat by radiation. Several methods and equations have been developed to determine with the highest accuracy the temperature of the cell taking into account these physical processes.

Under certain conditions (Ross, 1979), it is possible to simplify these equations and convert them in a linear equation as a function of the ambient temperature and the irradiance flux. Those conditions are not valid for all environments, for example for the planet Mars.

There are big differences between the environmental conditions on Earth and Mars that affect the temperature of a solar cell in Mars' surface. Mars atmosphere lacks of ultraviolet absorbers like ozone, and then extreme levels of UV radiation are reaching any solar cell located on its surface; and the low density of the atmosphere, composed mainly by $\mathrm{CO}_{2}$, is not a good refrigerator, even with wind 
speeds similar to those on Earth. As a consequence of these conditions, there are very large diurnal variations of temperature in Mars, making necessary the development of a particular cell temperature equation for the Mars environment, where cooling by convection and radiation are taken into account.

Mars exploration rovers powered by solar radiation have been a success previously (i.e, Mars Pathfinder http://www.nasa.gov/mission_pages/mars-pathfinder/, and the twins Spirit and Opportunity http://www.nasa.gov/ mission_pages/mer/index.html). The determination of an accurate operating cell temperature will optimize the efficiency of the performance of solar cells for future missions.

In this paper, we provide the equations to calculate the operating cell temperature taking into account the heating of the cell by solar radiation and its refrigeration by forced convection and radiation. In Section 2, we develop the general equation that should be used on Mars, considering all the physical processes that can be of importance on Mars. In Section 3, we present a linear simplification of the general equation dependent on air temperature, incident radiation and wind speed, and we prove its validity. In Section 4 we use the simplified linear expression to calculate the operating cell temperature on Mars based on air and ground temperature data provided by the Rover Environmental Monitoring Station (REMS) (Gómez-Elvira et al., 2012) on board the Curiosity rover currently on Mars (Grotzinger et al., 2012).

\section{General equation for the temperature of the solar cell, $\boldsymbol{T}_{c}$}

Skoplaki et al. (2008) proposed a number of relations to determine the temperature of a Photovoltaic (PV) cell depending on the environment conditions. These relations are extensively used on Earth (Townsend, 1989), being the simplest of them a linear relation between the cell temperature $\left(T_{c}\right)$ and the ambient temperature $\left(T_{a}\right)$ :

$T_{c}=T_{a}+k \phi_{s}$

where $k$ is the Ross coefficient (Ross, 1979) and $\phi_{s}$ the direct solar radiation.

This equation that comes from a simplification of the general equation (Skoplaki et al., 2008):

$T_{c}=\frac{T_{a}+\left(\frac{\phi_{s}}{\phi_{s, \text { NOCT }}}\right) \frac{U_{L, N O C T}}{U_{L}}\left(T_{c, N O C T}-T_{a, N O C T}\right)\left[1-\frac{\eta_{\text {ref }}}{(\tau \alpha)}\left(1+\beta_{r e f} T_{r e f}\right)\right]}{1-\frac{\beta_{r e f} \eta_{r e f}}{(\tau \alpha)}\left(\frac{G_{T}}{G_{N O C T}}\right) \frac{h_{w, N O C T}}{h_{w}}\left(T_{c, N O C T}-T_{a, N O C T}\right)}$

is not valid under Mars atmosphere conditions fundamentally because the atmosphere of Mars is extremely thin compared to the Earth's atmosphere, and the processes that could refrigerate the cell could be different. The ways in which a solar cell could loss heat are convection (forced, free or mixed) and radiation. On Earth, the forced convection is usually the only process taken into account, since it is several times more important than the other loss heat processes, as explained in Skoplaki et al. (2008). However, the assumption that only forced convection refrigerates a solar cell on Mars is wrong, because the losses by radiation account for at least three quarters of the total heat lost, and therefore all the equations determined under that hypothesis are incorrect (Osczevski, 2013).

The convective heat transfer at a surface is measured by the Nusselt $(N u)$ number, and its value depends on the type of convection (forced, free or mixed); and the type of convection which occurs under Mars atmosphere conditions is determined by relative values of the Reynolds $(R e)$ and Grashof $(\mathrm{Gr})$ dimensionless numbers. The Reynolds number is defined as the ratio of inertia to viscous forces:

$R e=\frac{u L}{v}$

and the Grashof number as the ratio of buoyancy to viscous forces:

$G r=\frac{g \beta\left(T_{s}-T_{a}\right) L^{3}}{v^{2}}$

The ratio $\mathrm{Gr} / \operatorname{Re}^{2}$ will determine the type of convection (Kays et al., 2004).

Obviously for Mars, the environmental values determining $\mathrm{Re}$ and $\mathrm{Gr}$ are different than those for Earth: the Martian atmosphere is about $95 \% \mathrm{CO}_{2}$ (for our purposes we will assume that is $100 \%$ of $\mathrm{CO}_{2}$ ), and typical values of density $(\rho)$ and kinematic viscosity $(v)$ are $(\rho)=0.01308 \mathrm{~kg} / \mathrm{m}^{3}$ and $(v)=0.0010868 \mathrm{~m}^{2} / \mathrm{s}$. For Earth these values are $(v)=1.460 \cdot 10^{-5} \mathrm{~m}^{2} / \mathrm{s}$ and $(\rho)=1.225 \mathrm{~kg} / \mathrm{m}^{3}$. Typical Martian values for surface and air temperature (at $1.5 \mathrm{~m}$ ) are $T_{s}=240$ and $T_{a}=220$, as can be deduced from REMS data (Gómez-Elvira et al., 2012), and therefore $\Delta T=20 \mathrm{~K}$. Considering a solar panel with length of $0.5 \mathrm{~m}$ and taking into account that the gravitational constant for Mars is $g=3.69 \mathrm{~m} / \mathrm{s}^{2}$, we obtain the ratio

$\frac{G r}{R e^{2}}=\frac{g \beta\left(T_{s}-T_{a}\right) L}{u^{2}}=\frac{3.69 \cdot 1 \cdot 20 \cdot 0.5}{220 \cdot u^{2}}=\frac{0.168}{u^{2}}$

Usual wind speeds in Mars range between $u=5 \mathrm{~m} / \mathrm{s}$ and $u=20 \mathrm{~m} / \mathrm{s}$. For these values the ratio of $G r$ and $R e$ numbers is always $\ll 1$, and therefore is possible to assume forced convection under Martian conditions (Incropera and DeWitt, 1996).

The Nusselt number is the dimensionless magnitude that characterizes the convective heat transfer at a surface. It depends on the type of convective heat transfer and also on the shape of the panel. For a flat plate, the expression for laminar flow is (Incropera and DeWitt, 1996):

$N u=\frac{h_{w} L}{k_{m}}=0.664 \operatorname{Re}^{1 / 2} \operatorname{Pr}^{1 / 3}$

where $h_{w}$ is the wind convection heat transfer coefficient [W m ${ }^{-2} \mathrm{~K}^{-1}$ ] and $k_{m}$ is the molecular thermal conductivity $\left[\mathrm{W} \mathrm{m}{ }^{-1} \mathrm{~K}^{-1}\right]$. $P r$ is the Prandtl number, defined as: 
$\operatorname{Pr}=\frac{\mu C_{p}}{k_{m}}$

where $\mu$ the dynamic viscosity of air, $C_{p}$ the specific heat of air at constant pressure and $k_{m}$ the molecular thermal conductivity. The relation between kinematic and dynamic viscosity is given by $v=\mu / \rho$.

Considering a thermal conductivity of $0.01465 \mathrm{~W} \mathrm{~m}^{-1} \mathrm{~K}^{-1}$ at $273 \mathrm{~K}$ and a specific heat of $850 \mathrm{~m}^{2} \mathrm{~s}^{-2} \mathrm{~K}^{-1}$ we can estimate the $\operatorname{Pr}$ number for Mars atmosphere as:

$\operatorname{Pr}=\frac{1.422 \cdot 10^{-5} \cdot 850}{1.465 \cdot 10^{-2}} \simeq 0.825$

For the sake of simplicity, we will consider the Prandtl number equal to 1 in this calculations, as it is assumed in General Circulation Models for Mars (Medvedev et al., 2006).

The relation between wind convection heat transfer coefficient and wind speed is therefore:

$h_{w}=\frac{k_{m}}{L} \cdot 0.664 \cdot\left(\frac{u L}{v}\right)^{1 / 2}$

Assuming that the atmosphere of Mars is nearly $100 \%$ of $\mathrm{CO}_{2}$ this equation can be written as:

$h_{w}=\frac{0.01465}{0.0010868^{1 / 2}} \cdot 0.664 \cdot\left(\frac{u}{L}\right)^{1 / 2}$

$h_{w}=0.295 \cdot\left(\frac{u}{L}\right)^{1 / 2}$

The radiation losses on Mars are very important and must be considered for the correct estimation of the temperature of the cell. Convection constitutes only one quarter of the heat transfer on Mars, and therefore radiation must be considered (Osczevski, 2013).

The radiation heat transfer coefficient can be written as (Eckstein, 1990):

$h_{\text {rad }}=\epsilon \sigma\left(T_{c}^{2}+T_{a}^{2}\right)\left(T_{c}-T_{a}\right)$

i.e., it is dependent on the temperature of the body itself, the temperature of the cell $\left(T_{c}\right)$ in our case.

We need to take into account that the temperature of the cell will be intrinsically coupled to the temperature of the platform (in the case of a cell in a rover or lander) or the surface if it is lying directly on the ground. In those cases, the temperature must be determined considering heat conduction instead of convection, and it will be mainly determined by the temperature of the hosting body.

Therefore, an iteration process will be needed in order to calculate it. The convergence is reached after five iterations and a good assumption for the starting seed could be $T_{c}=T_{a}+20 \mathrm{~K}$. In Figs. 1 and 2 we show the temperatures of the air and the cell.

Hence, the overall loss coefficient, $U_{L}$, is the sum of the wind and radiation coefficients (Eckstein, 1990), i.e., $U_{L}=h_{w}+h_{\text {rad }}$ :

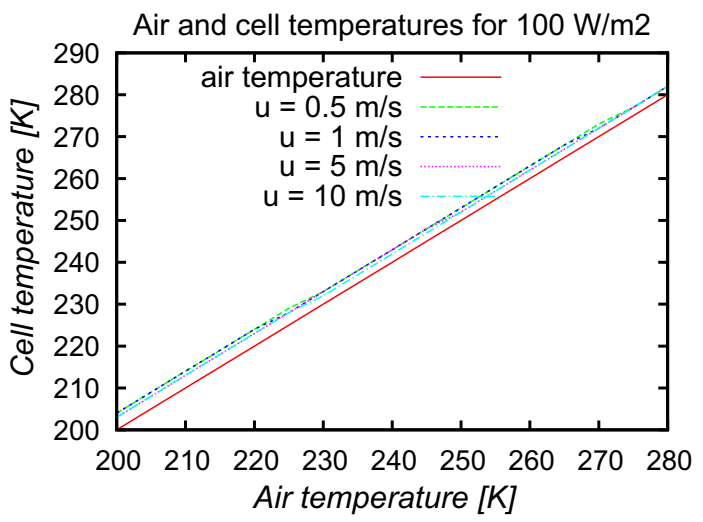

Fig. 1. Air and cell temperatures for solar flux of $100 \mathrm{~W} / \mathrm{m}^{2}$.

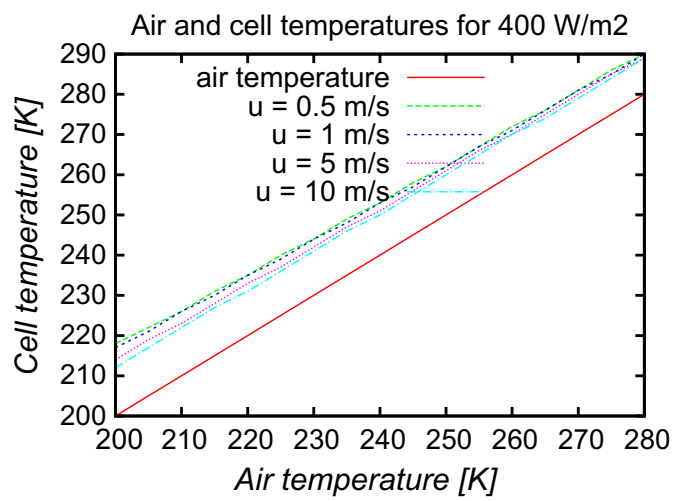

Fig. 2. Air and cell temperatures for solar flux of $400 \mathrm{~W} / \mathrm{m}^{2}$.

$U_{L}=0.295 \cdot\left(\frac{u}{L}\right)^{1 / 2}+\epsilon \sigma\left(T_{c}^{2}+T_{a}^{2}\right)\left(T_{c}+T_{a}\right)$

In order to provide an useful approximation of the cell temperature, we must consider the radiation reaching the surface, $\phi_{s}$. On Earth, the mean irradiance is $S_{0}=1380 \mathrm{~W} \mathrm{~m}^{-2}$ at the top of the atmosphere. The irradiance on Mars TOA $\left(\phi_{\text {Mars }}\right)$ can be computed by simple geometrical scaling as:

$\phi_{\text {Mars }}=S_{0} \cdot \frac{R_{0}^{2}}{R_{\text {Mars }}^{2}} \cdot \cos (\theta)$

where $\theta$ depends on latitude and Ls. At a latitude of $23^{\circ} \mathrm{S}$ during the summer time, where the maximum is accomplished, for an average distance of Mars of 1.524 AU, we obtain

$\phi_{\text {Mars }}=1380 \cdot \frac{1}{1.524^{2}} \simeq 600 \mathrm{~W} \mathrm{~m}^{-2}$

at the top of the atmosphere. Considering an opacity index of $\gamma=0.3$ (Lemmon, 2014), the reference value for the irradiance on the surface could be $\phi_{s}=444.5 \mathrm{~W} \mathrm{~m}^{-2}$ (more than 3 times smaller than on Earth). Note that the opacity value depends on the atmospheric dust load, that change along the day and seasons in Mars (see Table 1).

For our estimation, we will use the Nominal Operating Cell Temperature (NOCT) and reference values cited in 
Skoplaki et al. (2008), summarized in Table 2, that allow to compare the results for Mars and Earth.

For a wind speed of $10 \mathrm{~m} / \mathrm{s}$, the second part of the denominator becomes $0.002530 \ll 1$, and can be neglected. In the numerator, the second part reads:

$\left(\frac{\phi_{s}}{\phi_{s, N O C T}}\right) \frac{U_{L, N O C T}}{U_{L}}\left(T_{c, N O C T}-T_{a, N O C T}\right)\left[1-\frac{\eta_{r e f}}{(\tau \alpha)}\left(1+\beta_{r e f} T_{r e f}\right)\right]$

For a wind speed of $10 \mathrm{~m} / \mathrm{s}$, the value is $3.27 \mathrm{~K}$, and for $20 \mathrm{~m} / \mathrm{s}$ is $2.31 \mathrm{~K}$. This part of the equation cannot be neglected and even less knowing the very important variations of irradiance and wind speed on Mars.

Eq. (2) can be simplified as:

$T_{c}=T_{a}+\left(\frac{\phi_{s}}{\phi_{s, N O C T}}\right) \frac{U_{L, N O C T}}{U_{L}}\left(T_{c, N O C T}-T_{a, N O C T}\right)\left[1-\frac{\eta_{r e f}}{(\tau \alpha)}\left(1+\beta_{r e f} T_{r e f}\right)\right]$

$T_{c}=T_{a}+\left(\frac{\phi_{s}}{\phi_{s, N O C T}}\right) \frac{U_{L, N O C T}}{0.295 \cdot\left(\frac{u}{L}\right)^{1 / 2}+\epsilon \sigma\left(T_{s}^{2}+T_{a}^{2}\right)\left(T_{s}+T_{a}\right)}$.

$\left(T_{c, N O C T}-T_{a, N O C T}\right)\left[1-\frac{\eta_{r e f}}{(\tau \alpha)}\left(1+\beta_{r e f} T_{r e f}\right)\right]$

\section{Simplified linear equation for $T_{c}$}

Assuming a square cell $1 \mathrm{~m}$ side, Eq. (17) can be simplified in order to compute the temperature of a solar cell as a function of ambient temperature, solar flux and wind velocity. After Eq. (17) we can generate a dataset for the different values of the variables, which can be easily fitted into a multivariable linear expression. The dataset is summarized in Tables 3-7, where the temperature of the cell is computed for different values of the variables in the typical ranges of variation on Mars. The solar irradiance varies typically between 0 and $400 \mathrm{~W} / \mathrm{m}^{2}$ as calculated before, considering a dust opacity of 0.3 . Expected wind speed variations are in the range of $0-20 \mathrm{~m} / \mathrm{s}$, being $20 \mathrm{~m} / \mathrm{s}$ dust devil conditions, and REMS measurements provide ambient temperatures in the range of 200-290 K (Gómez-Elvira et al., 2014).

The most accurate linear expression that fit those variables in the mentioned ranges is:

$T_{c}=1.00116 \cdot T_{a}+0.0313174 \cdot \phi_{s}-0.108832 \cdot u$

Table 8 shows a comparison between the results obtained with Eqs. (17) and (18), showing that the difference between the exact equation and the approximation is negligible and therefore Eq. (18) can be used with confidence.

Key factors determining the cell temperature are the ambient temperature, the irradiance over the cell and the wind speed. In Mars, the typical values of wind speed are between 1 and $20 \mathrm{~m} / \mathrm{s}$, and therefore the contribution of the wind speed refrigerating the solar cell is about $-2.2 \mathrm{~K}$. On the other hand, the irradiance reaching the panel once it passes through the atmosphere is about $444.5 \mathrm{~W} / \mathrm{m}^{2}$ at noon, and therefore its contribution to the
Table 1

List of symbols and constants.

\begin{tabular}{|c|c|}
\hline$\overline{\phi_{s}}$ & Radiation flux $\left(\mathrm{W} \mathrm{m}^{-2}\right)$ \\
\hline$A_{\text {cell }}$ & Cell area $\left(\mathrm{m}^{2}\right)$ \\
\hline$T_{a}$ & Air/ambient temperature (K) \\
\hline$T_{c}$ & Temperature of the cell $(\mathrm{K})$ \\
\hline$k$ & Ross coefficient \\
\hline NOCT & Nominal Operating Cell Temperature \\
\hline$U_{L}$ & Overall loss coefficient \\
\hline$U_{L, N O C T}$ & Overall loss coefficient at NOCT conditions \\
\hline$h_{w}$ & Wind convection heat transfer coeff. $\left(\mathrm{W} \mathrm{m} \mathrm{K}^{2} \mathrm{~K}^{-1}\right)$ \\
\hline$h_{w, N O C T}$ & $h_{w}$ at NOCT \\
\hline$h_{\text {rad }}$ & Raditive heat transfer coeff. ( $\mathrm{W} \mathrm{m}^{2} \mathrm{~K}^{-1}$ ) \\
\hline $\mathrm{h}_{\text {rad,NOCT }}$ & $h_{\text {rad }}$ at NOCT \\
\hline$\epsilon$ & Emissivity \\
\hline$T_{c, N O C T}$ & Temperature of the cell at NOCT \\
\hline$T_{a, N O C T}$ & Temperature of the air at NOCT \\
\hline$\eta_{\text {ref }}$ & Reference cell electric efficiency \\
\hline$T_{r e f}$ & Reference cell temperature \\
\hline$\tau$ & Transmittance of glazing \\
\hline$\alpha$ & Solar absorptance of PV layer \\
\hline$u$ & Free-stream velocity of air $\left(\mathrm{m} \mathrm{s}^{-1}\right)$ \\
\hline$L$ & Characteristic length $(\mathrm{m})$ \\
\hline$v$ & Kinematic viscosity $\left(\mathrm{m}^{2} \mathrm{~s}^{-1}\right)$ \\
\hline$k_{m}$ & Molecular thermal conductivity $\left(\mathrm{W} \mathrm{m}^{-1} \mathrm{~K}^{-1}\right.$ ) \\
\hline$v$ & Kinematic viscosity of air $\left(\mathrm{m}^{2} \mathrm{~s}^{-1}\right)$ \\
\hline$g$ & Gravitational constant $\left(\mathrm{m} \mathrm{s}^{-2}\right)$ \\
\hline$\rho$ & Density $\left(\mathrm{kg} \mathrm{m}^{-3}\right)$ \\
\hline$\mu$ & Dynamic viscosity $\left(\mathrm{N} \mathrm{s} \mathrm{m}^{-2}\right)$ \\
\hline$C_{p}$ & Specific heat $\left(\mathrm{J} \mathrm{kg}^{-1} \mathrm{~K}^{-1}\right)$ \\
\hline$\beta$ & $1 / T_{a}=$ coefficient of thermal expansion $\left(\mathrm{K}^{-1}\right)$ \\
\hline$\beta_{r e f}$ & $1 / T_{r e f}=$ coefficient of thermal expansion $\left(\mathrm{K}^{-1}\right)$ \\
\hline$T_{s}$ & Surface temperature $(\mathrm{K})$ \\
\hline$G r$ & Grashof number \\
\hline $\operatorname{Re}$ & Reynolds number \\
\hline $\operatorname{Pr}$ & Prandtl number \\
\hline$N u$ & Nusselt number \\
\hline$\gamma$ & Opacity index \\
\hline$\theta$ & Solar zenith angle \\
\hline$\phi_{s, N O C T}$ & Radiation flux at NOCT \\
\hline$R_{0}$ & Earth's radium \\
\hline$R_{\text {Mars }}$ & Mars' radium \\
\hline
\end{tabular}

Table 2

NOCT reference values.

\begin{tabular}{ll}
\hline$u_{N O C T}$ & $1 \mathrm{~m} / \mathrm{s}$ \\
$T_{a, N O C T}$ & $20^{\circ} \mathrm{C}$ \\
$G_{T, N O C T}$ & $800 \mathrm{~W}$ \\
$T_{c, N O C T}$ & $47^{\circ} \mathrm{C}$ \\
$\eta_{r e f}$ & 0.12 \\
$\beta_{r e f}$ & $0.004{ }^{\circ} \mathrm{C}^{-1}$ \\
$T_{r e f}$ & $25^{\circ} \mathrm{C}$ \\
$\tau \alpha$ & 0.9 \\
\hline
\end{tabular}

Table 3

Cell temperatures as a function of $\phi_{s}$ and $u\left(T_{a}=200 \mathrm{~K}\right)$.

\begin{tabular}{lllll}
\hline & $0.5 \mathrm{~m} / \mathrm{s}$ & $1 \mathrm{~m} / \mathrm{s}$ & $5 \mathrm{~m} / \mathrm{s}$ & $10 \mathrm{~m} / \mathrm{s}$ \\
\hline $100 \mathrm{~W} / \mathrm{m}^{2}$ & 204,9083 & 204,6548 & 203,8172 & 203,3611 \\
$200 \mathrm{~W} / \mathrm{m}^{2}$ & 209,528 & 209,0618 & 207,4953 & 206,6265 \\
$300 \mathrm{~W} / \mathrm{m}^{2}$ & 213,8946 & 213,2484 & 211,0441 & 209,8012 \\
$400 \mathrm{~W} / \mathrm{m}^{2}$ & 218,0371 & 217,2375 & 214,4726 & 212,8898 \\
\hline
\end{tabular}


Table 4

Cell temperatures as a function of $\phi_{s}$ and $u\left(T_{a}=220 \mathrm{~K}\right)$.

\begin{tabular}{lllll}
\hline & $0.5 \mathrm{~m} / \mathrm{s}$ & $1 \mathrm{~m} / \mathrm{s}$ & $5 \mathrm{~m} / \mathrm{s}$ & $10 \mathrm{~m} / \mathrm{s}$ \\
\hline $100 \mathrm{~W} / \mathrm{m}^{2}$ & 224,1930 & 224,0205 & 223,4237 & 223,0795 \\
$200 \mathrm{~W} / \mathrm{m}^{2}$ & 228,1851 & 227,8632 & 226,7361 & 226,0775 \\
$300 \mathrm{~W} / \mathrm{m}^{2}$ & 231,9967 & 231,5446 & 229,9445 & 228,9983 \\
$400 \mathrm{~W} / \mathrm{m}^{2}$ & 235,6455 & 235,0792 & 233,0556 & 231,8456 \\
\hline
\end{tabular}

Table 5

Cell temperatures as a function of $\phi_{s}$ and $u\left(T_{a}=240 \mathrm{~K}\right)$.

\begin{tabular}{lllll}
\hline & $0.5 \mathrm{~m} / \mathrm{s}$ & $1 \mathrm{~m} / \mathrm{s}$ & $5 \mathrm{~m} / \mathrm{s}$ & $10 \mathrm{~m} / \mathrm{s}$ \\
\hline $100 \mathrm{~W} / \mathrm{m}^{2}$ & 243,6343 & 243,5142 & 243,0828 & 242,8223 \\
$200 \mathrm{~W} / \mathrm{m}^{2}$ & 247,1252 & 246,8983 & 246,0770 & 245,5763 \\
$300 \mathrm{~W} / \mathrm{m}^{2}$ & 250,4851 & 250,1629 & 248,9879 & 248,2653 \\
$400 \mathrm{~W} / \mathrm{m}^{2}$ & 253,7245 & 253,3169 & 251,8203 & 250,8925 \\
\hline
\end{tabular}

Table 6

Cell temperatures as a function of $\phi_{s}$ and $u\left(T_{a}=260 \mathrm{~K}\right)$.

\begin{tabular}{lllll}
\hline & $0.5 \mathrm{~m} / \mathrm{s}$ & $1 \mathrm{~m} / \mathrm{s}$ & $5 \mathrm{~m} / \mathrm{s}$ & $10 \mathrm{~m} / \mathrm{s}$ \\
\hline $100 \mathrm{~W} / \mathrm{m}^{2}$ & 263,1937 & 263,1080 & 262,7911 & 262,5926 \\
$200 \mathrm{~W} / \mathrm{m}^{2}$ & 266,2825 & 266,1190 & 265,5116 & 265,1284 \\
$300 \mathrm{~W} / \mathrm{m}^{2}$ & 269,2738 & 269,0398 & 268,1652 & 267,6098 \\
$400 \mathrm{~W} / \mathrm{m}^{2}$ & 272,1745 & 271,8761 & 270,7554 & 270,0395 \\
\hline
\end{tabular}

Table 7

Cell temperatures as a function of $\phi_{s}$ and $u\left(T_{a}=280 \mathrm{~K}\right)$.

\begin{tabular}{lllll}
\hline & $0.5 \mathrm{~m} / \mathrm{s}$ & $1 \mathrm{~m} / \mathrm{s}$ & $5 \mathrm{~m} / \mathrm{s}$ & $10 \mathrm{~m} / \mathrm{s}$ \\
\hline $100 \mathrm{~W} / \mathrm{m}^{2}$ & 282,8423 & 282,7798 & 282,5431 & 282,3904 \\
$200 \mathrm{~W} / \mathrm{m}^{2}$ & 285,6058 & 285,4857 & 285,0294 & 284,7334 \\
$300 \mathrm{~W} / \mathrm{m}^{2}$ & 288,2954 & 288,1221 & 287,4616 & 287,0311 \\
$400 \mathrm{~W} / \mathrm{m}^{2}$ & 290,9154 & 290,6930 & 289,8423 & 289,2854 \\
\hline
\end{tabular}

Table 8

Exact and predicted temperatures.

\begin{tabular}{llllll}
\hline$T_{a}$ & $\phi_{s}$ & $u$ & Exact $T_{c}$ & Predicted $T_{c}$ & Difference $(\%)$ \\
\hline 215 & 130 & 1 & 220.37 & 219.21 & 0.52 \\
240 & 140 & 3.5 & 244.45 & 244.28 & 0.07 \\
280 & 200 & 1.5 & 285.40 & 286.42 & 0.35 \\
215 & 390 & 11 & 226.62 & 226.26 & 0.15 \\
\hline
\end{tabular}

cell temperature is about $12.7 \mathrm{~K}$. However, wind on Mars must be taken into account because it changes significantly along the martian day.

\section{4. $T_{c}$ daily variations on Mars}

In this section we evaluate the daily variations of the temperature of a solar cell temperature on Mars. For that we use measurements from the Rover Environmental Monitoring Station (REMS) on the Curiosity rover that is operating in Mars since August 2012 (Gómez-Elvira et al., 2012).

Two different types of solar cells have powered rovers in Mars: those lying on the ground (i.e., Mars Pathfinder),

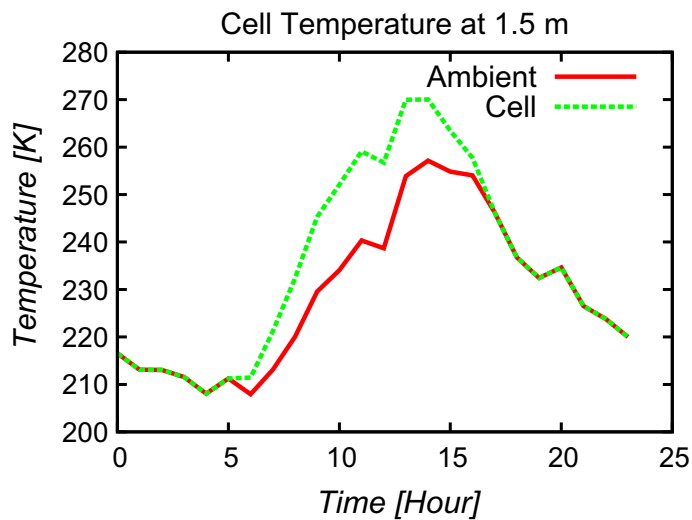

Fig. 3. Ambient and cell temperature on Mars at Gale coordinates using REMS data.

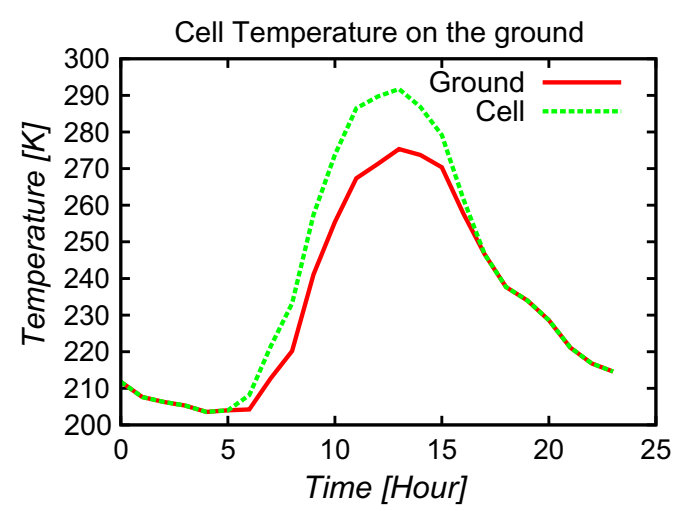

Fig. 4. Ground and cell temperature on Mars at Gale coordinates using REMS data.

and those at some distance above the surface (i.e., Siprit and Opportunity). On Earth, the difference between the temperatures on the ground and, for Example $1.5 \mathrm{~m}$ altitude are negligible, but that difference on Mars is remarkably important (about $20 \mathrm{~K}$ at noon in Equatorial regions). It is therefore important to distinguish between these situations. In order to do that, we will use the $1.5 \mathrm{~m}$ temperature measured by REMS with the Air Temperature Sensor (ATS) (Gómez-Elvira et al., 2012; Gómez-Elvira et al., 2014) for the Spirit-like panels and the ground temperature provided by the Ground Temperature Sensor (GTS) for those panels lying on the ground like the Mars Pathfinder ones.

Additionally, the difference in wind velocities in altitude is very important. The order of magnitude at the ground is about $0.5 \mathrm{~m} / \mathrm{s}$, which means that the wind term in Eq. (18) can be neglected, but at $1.5 \mathrm{~m}$ the order of magnitude is $7-$ $10 \mathrm{~m} / \mathrm{s}$, making an effect in the temperature, and should be used. Unfortunately, the wind speed sensor on REMS was damaged during the landing, and there is no real data available at this point. To estimate the wind speed and solve the lack of data, we have used the values between $0.5-$ and $20-\mathrm{m} / \mathrm{s}$ as suggested by Mars mesoscale models. 
In Figs. 3 and 4 we show the ambient temperature measured by REMS at solar longitude (Ls) 270 and the calculated temperature of an hypothetical solar cell standing on Mars. We have used the Gale Crater coordinates $\left(4^{\circ} 36 \mathrm{~S}\right.$ $137^{\circ} 12 \mathrm{E}$ ) to estimate the irradiance reaching the panel.

\section{Conclusions}

On Earth the simplest equation for the temperature of a cell depends on the ambient temperature and the incident solar radiation:

$T_{c}=T_{a}+k \phi_{s}$

The main uncertainty in this equation is the value of the Ross coefficient, $k$, with values between 0.021 and 0.054 (Nordmann and Clavadetscher, 2003).

Here we show that a similar linear expression can be found for Mars environment, depending on ambient temperature, incident solar radiation, and wind speed:

$T_{c}=1.00116 \cdot T_{a}+0.0313174 \cdot \phi_{s}-0.108832 \cdot u$

The operating temperature of a solar cell is an important factor determining the efficiency and performance of the solar radiation conversion. The general equation to determine the temperature of the solar cell depends on the different ways of refrigeration that might affect the panel, which is related with the environment. Usually, on Earth, only forced convection is considered, and simply linear expressions have been proposed to determine the effective temperature of the panel. However, on Mars, the radiation losses are extremely important because of the characteristics of the extreme environment, and the equations developed for Earth conditions are not valid.

Wind on Mars is very important and it might have strong variations within a day. We provide a way to quantify the value of the refrigeration by wind convection over the solar cell, which may change the solar cell temperature up to $2.5^{\circ}$.

Considering convection and radiation losses, an iteration process has been carried out until convergence to determine the operating temperature of a solar cell on Mars. The results have been fitted to a linear expression depending on ambient temperature, solar irradiance and wind speed. We reach an equation similar to the usually used on Earth with an additional term accounting for the loss of heat by convection, which is proportional to the wind speed.

\section{Acknowledgements}

This work was partially supported by the INTA Grant TD 04/10 at the Spanish Center of Astrobiology (INTA-CSIC). F.J. Martín-Torres would like to acknowledge financial support provided by the Spanish Ministry of Economy and Competitiveness (AYA2011-25720 and
AYA2012-38707). The authors want to thanks to the entire Planetary Sciences and Habitability group from IACT for the support and comments on the draft.

\section{References}

Eckstein, J.H., 1990. Detailed Modelling of Photovoltaic System Components. M.S. Thesis, Mechanical Engineering, University of Wisconsin-Madison.

Gómez-Elvira, J., Armiens, C., Castaner, L., Domínguez, M., Genzer, M., Gómez, F., Haberle, R., Harri, A-M., Jimenez, V., Kahanpaa, H., Kowalski, L., Lepinette, A., Martínez-Frías, J., Martín, J., McEwan, I., Mora, L., Moreno, J., Navarro, S., de Pablo, M.A., Peinado, V., Pena, A., Polkko, J., Ramos, M., Renno, N.O., Ricart, J., Richardson, M., Rodríguez-Manfredi, J., Romeral, J., Sebastián, E., Serrano, J., de la Torre Juárez, M., Torres, J., Torrero, F., Urqui, R., Velasco, T., Verdasca, J., Zorzano, M.-P., Martín-Torres, F.J., 2012. REMS: an environmental sensor suite for the Mars Science Laboratory. Space Sci. Rev. 170, 556.

Gómez-Elvira, J., Armiens, C., Carrasco, I., Genzer, M., Gómez, F., Haberle, R., Hamilton, V.E., Harri, A-M., Kahanp, H., Kemppinen, O., Lepinette, A., Martín-Soler, J., Martń-Torres, J., Martínez-Frías, J., Mischna, M., Mora, L., Navarro, S., Newman, C., de Pablo, M.A., Peinado, V., Polkko, J., Rafkin, S.C.R., Ramos, M., Rennó, N.O., Richardson, M., Rodríguez-Manfredi, J.A., Romeral Planelló, J.J., Sebastián, E., de la Torre Juárez, M., Torres, J., Urquí, R., Vasavada, A.R., Verdasca, J., Zorzano, M.-P., 2014. Curiosity's rover environmental monitoring station: overview of the first 100 sols. J. Geophys. Res.: Planets. http://dx.doi.org/10.1002/2013JE004576 [in press].

Grotzinger, J.P., Crisp, J., Vasavada, A.R., Anderson, R.C., Baker, C.J., Barry, R., Blake, D.F., Conrad, P., Edgett, K.S., Ferdowski, B., Gellert, R., Gilbert, J.B., Golombek, M., Gmez-Elvira, J., Hassler, D.M., Jandura, L., Litvak, M., Mahaffy, P., Maki, J., Meyer, M., Malin, M.C., Mitrofanov, I., Simmonds, J.J., Vaniman, D., Welch, R.V., Wiens, R.C., 2012. Mars Science Laboratory mission and science investigation. Space Sci. Rev. 170 (1-4), 5-56.

Incropera, F.P., DeWitt, D.P., 1996. Fundamentals of Heat and Mass Transfer, fourth ed. John Wiley \& Sons, New York.

http://www.nasa.gov/mission_pages/mer/index.html.

Kays, W., Crawford, M., Weigand, B., 2004. Convective Heat and Mass Transfer, fourth ed. McGraw-Hill Professional, ISBN 0072990732.

Lemmon, M.T., 2014. The Mars Science Laboratory optical depth record. In: Eighth International Conference on Mars, 2014.

Medvedev, A.S., Hartogh, P., Kuroda, T., Saito, R., Feolov, A.G., Kutepov, A.A., 2006. A new general circulation model of the Martian atmosphere: description and first results. In: Second Workshop on Mars Atmosphere Modelling and Observations, March, 2006, Granada, Spain.

Nordmann, T., Clavadetscher, L., 2003. Understanding temperature effects on PV system performance. In: Proceedings of the Third World Conference on Photovoltaic Energy Conversion, May 1118, Osaka, Japan, 2003, pp. 2243-2246.

Osczevski, R., 2013. Martian windchill in terrestrial terms. Bull. Am. Meteorol. Soc. 95 (4), 533-541.

http://www.nasa.gov/mission_pages/mars-pathfinder/.

Ross, R.G., 1979. Interface design considerations for terrestrial solar cell modules. In: Proceedings of the 12th IEEE Photovoltaic Specialists Conference, Baton Rouge, LA, pp. 801-806.

Skoplaki, E., Boudouvis, A.G., Palyvos, J.A., 2008. A simple correlation for the operating temperature of photovoltaic modules of arbitrary mounting. Sol. Energy Mater. Sol. Cells 92 (11), 1393-1402.

Townsend, T.U., 1989. A Method for Estimating the Long-Term Performance of Direct Coupled Photovoltaic Systems. M.S. Thesis, Mechanical Engineering, University of Wisconsin-Madison. 